\section{A carbon dioxide tolerant aqueous- electrolyte-free anion-exchange membrane alkaline fuel cell}

\author{
Latifah A. Adams, ${ }^{[a]}$ Simon D. Poynton, ${ }^{[a]}$ Christelle \\ Tamain, ${ }^{[b]}$ Robert C. T. Slade,${ }^{[a]}$ and John R. Varcoe ${ }^{\star[a]}$
}

Despite over a century of study and decades of intensive research, few fuel cell products have appeared on the market. ${ }^{[1]}$ The major inhibitor to mass commercialisation is cost. ${ }^{[2]} \mathrm{H}_{2} /$ air alkaline fuel cells (AFCs) containing $\mathrm{KOH}(\mathrm{aq})$ electrolyte promise the lowest cost devices, ${ }^{[3,4]}$ with the ability to use non-Pt catalysts. The fundamental problem with AFCs is that the $\mathrm{KOH}(\mathrm{aq})$ electrolyte reacts with $\mathrm{CO}_{2}$ (cathode air supply) to form carbonate species, which lowers cell performance and lifetime (formation of carbonate precipitates in electrodes and reduction of $\mathrm{OH}^{-}$concentration in electrolyte). ${ }^{[4,5]}$ However, the carbonate content of a aqueous-electrolyte-free (metal-cation-free) alkaline anion-exchange membrane (AAEM), that was pre-exchanged to the $\mathrm{CO}_{3}{ }^{2-}$ form, decreased when operated in $\mathrm{H}_{2}$ /air and methanol/air fuel cells. This remarkable result is contrary to prior wisdom; AAEMs inherently prevent carbonate performance losses when incorporated into AFCs. This experiment was made possible only by the recent breakthrough development of an alkaline interface ionomer, ${ }^{[6]}$ which allows fabrication of membrane electrode assemblies that do not require incorporation of metal hydroxides species to perform well. ${ }^{[7]}$

The widely perceived advantages of alkaline membrane direct alcohol fuel cells (AMDAFC) are the potential use of relatively inexpensive and abundant non-Pt electrocatalysts (as with the $\mathrm{H}_{2}$ /air AFCs), ${ }^{\left[{ }^{8-10]}\right.}$ reduced alcohol crossover, ${ }^{[11,12]}$ and enhanced electro-oxidation of high energy density alcoholic fuels. ${ }^{[13]}$ However, metal hydroxides have traditionally been used as an additive, either in the electrode architectures ${ }^{[7]}$ or in the aqueous alcohol supplies ${ }^{[11]}$ due to the previous lack of an alkaline analogue to the perfluorosulfonic acid dispersions, ${ }^{[14]}$ required for high-performance membrane electrode assemblies (MEAs) for

[a] Dr. J. Varcoe, L. Adams, S. Poynton, and Prof. R. Slade Department of Chemistry

The University of Surrey

Guildford, GU2 7XH (United Kingdom)

Fax: (+44) 1483686838

E-mail: j.varcoe@surrey.ac.uk

Homepage: http://mypages.surrey.ac.uk/chs1jv

[b] C. Tamain is an undergraduate student at L'Ecole Nationale Supérieure de Chimie de Paris (France) on summer placement at Surrey.

Supporting information for this article is available on the WWW under http://www.chemsuschem.org or from the author. proton-exchange membrane fuel cells (PEMFCs). Concerns persist about the effect of carbonate formation with such AMDAFCs. ${ }^{[15]}$ The hypothesis that was tested in this study is that the tendency to form $\mathrm{CO}_{3}{ }^{2-}$ can be reduced on the elimination of $\mathrm{M}^{\mathrm{n+}}$ from AAEM-based solid alkaline fuel cells (SAFCs); precipitates of metal carbonates ${ }^{[4]}$ cannot then form (the counter $-\mathrm{N}^{+} \mathrm{R}_{3}$ cations are covalently bound to the polymer electrolyte analogous to the $-\mathrm{SO}_{3}{ }^{-}$counter anions in PEMs).

\begin{tabular}{|lllll|}
\hline \multicolumn{2}{|l|}{ Table 1. Select AAEM properties } \\
Anion & $\begin{array}{l}I E C^{[\mathrm{a}]} / \mathrm{meq} \\
\mathrm{g}^{-1}\end{array}$ & $\begin{array}{l}t_{F H} \\
\mu \mathrm{m}\end{array}$ & $\left(t_{D H}\right)^{[\mathrm{b}]} / \lambda^{[\mathrm{c}]}$ & $\begin{array}{l}\sigma^{[\mathrm{d}]} \\
/ \mathrm{mS} \mathrm{cm}^{-1}\end{array}$ \\
\hline $\mathrm{CO}_{3}^{2-}$ & $1.28 \pm 0.01$ & $\left.\begin{array}{l}154 \pm 5(139 \\
\pm 5\end{array}\right)$ & $12.8 \pm 0.2$ & $7.7 \pm 0.8$ \\
$\mathrm{OH}^{-}$ & $1.14 \pm 0.02$ & $\left.\begin{array}{l}153 \pm 4(133 \\
\pm 4\end{array}\right)$ & $16 \pm 1$ & $8.8 \pm 0.6$ \\
& & & \\
\hline
\end{tabular}

[a] lon-exchange capacities (amount of anion per gram of dry membrane) [b] Thicknesses of the AAEM when fully hydrated $(\mathrm{FH})$ and dehydrated $(\mathrm{DH})[\mathrm{c}]$ Water contents of the FH-AAEM (number of $\mathrm{H}_{2} \mathrm{O}$ molecules per polymer anionexchange site) [d] Through-plane anion conductivities (static $\mathrm{RH}=100 \%$ environment at $30^{\circ} \mathrm{C}$ ).

The data presented in Table 1 compare the ex situ properties of the AAEM in $\mathrm{CO}_{3}{ }^{2-}$ and $\mathrm{OH}^{-}$forms; the properties do not vary substantially. Importantly, the through-membrane conductivities at $30^{\circ} \mathrm{C}$ in a static relative humidity $(\mathrm{RH})=100 \%$ atmosphere were similar. The ionic performance of AAEMs would not be seriously compromised even on substantial formation of carbonate.

Peak power densities of $37.9 \pm 1.4 \mathrm{~mW} \mathrm{~cm}^{-2}$ were obtained in $\mathrm{H}_{2}$ /air fuel cell tests with the AAEM MEAs in $\mathrm{CO}_{3}{ }^{2-}$ form (Figure 1); this was higher than the $32.9 \pm 1.6 \mathrm{~mW} \mathrm{~cm}^{-2}$ obtained with the $\mathrm{OH}^{-}$benchmarks. The respective in situ cell resistances of $1.5 \pm$ $0.2 \Omega \mathrm{cm}^{2}$ and $1.7 \pm 0.2 \Omega \mathrm{cm}^{2}$ showed that there was only a small increase in the contact resistance for the latter. This finding correlates with previous preliminary observations that the oxygen reduction reaction proceeds more rapidly in alkaline carbonate (with strongly adsorbing $\mathrm{CO}_{3}{ }^{2-}$ anions) than in $\mathrm{KOH}(\mathrm{aq})$ solutions (weaker adsorbing $\mathrm{OH}^{-}$anions); ${ }^{[16]}$ the mechanism for this is not fully understood. Operation of the $\mathrm{OH}^{-}$form AAEM in $\mathrm{H}_{2} / \mathrm{O}_{2}$ tests yielded peak power performances of $51 \pm 5 \mathrm{~mW} \mathrm{~cm}^{-2}(n=5)$; the lower performances observed with air rather than pure $\mathrm{O}_{2}$ originate from the anticipated increase in mass transport losses (dilution of oxidant). ${ }^{[17]}$

The post-mortem Raman analyses (Figure 2) of the AAEMs that were originally in the $\mathrm{CO}_{3}{ }^{2-}$ form shows a reduction of the intensity of the carbonate $\mathrm{C}-\mathrm{O}$ symmetric stretch at $1067 \mathrm{~cm}^{-1}$ (observed in the Raman spectrum of the pre-test AAEMs). The intensity $\left(I_{\text {norm }}\right)$ of the carbonate peak was consistently 0.30 pretest and $0.13 \pm 0.09$ post-test $\left(I_{\text {norm }}<0.04\right.$ in the post-mortem spectra of the $\mathrm{OH}^{-}$-form AAEMs benchmarks). The $\mathrm{CO}_{3}{ }^{2-}$ content of the AAEM evidently decreased (i.e. self-purging) when operated in a $\mathrm{H}_{2}$ /air fuel cell, with continuous generation of $\mathrm{OH}^{-}$anions from the oxygen reduction reaction at the cathode $\left(\mathrm{O}_{2}\right.$ $\left.+2 \mathrm{H}_{2} \mathrm{O}+4 \mathrm{e}^{-} \rightarrow 4 \mathrm{OH}^{-}\right)$. 


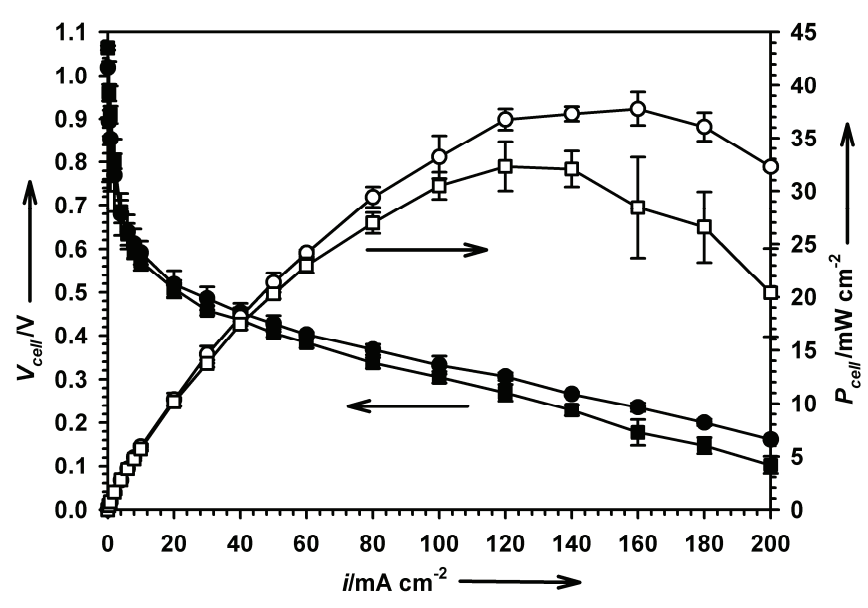

Figure 1. The $\mathrm{H}_{2}$ /air fuel cell performance curves at $50{ }^{\circ} \mathrm{C}$ obtained with the $\mathrm{CO}_{3}{ }^{2-}$ form AAEMs (circles) and with the $\mathrm{OH}^{-}$form AAEMs (squares).

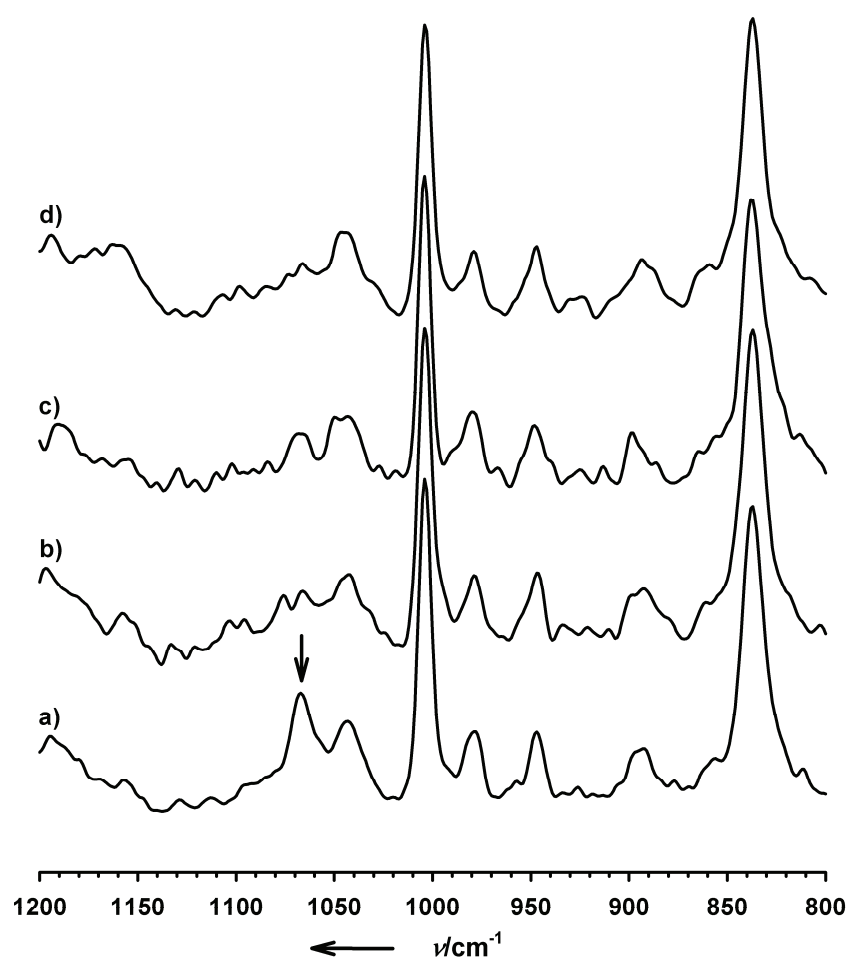

Figure 2. The FT-Raman spectra of (a) a freshly prepared $\mathrm{CO}_{3}{ }^{2-}$ form $\mathrm{AAEM}$, (b) a post-mortem sample after a $\mathrm{CO}_{3}{ }^{2-}$-AAEM test, (c) a freshly prepared $\mathrm{OH}^{-}$form AAEM (d) a post-mortem sample after a $\mathrm{OH}^{-}$-AAEM test. The vertical arrow indicates the distinctive $\mathrm{CO}_{3}{ }^{2-}$ band.

A previous $233 \mathrm{~h}$ galvanic discharge test, with this AAEM, showed that the small voltage losses $\left(<100 \mu \mathrm{V} \mathrm{h} h^{-1}\right)$ were recoverable and that the membrane IEC was not significantly degraded. ${ }^{[6]}$ When combined with the findings of previous studies, ${ }^{[18,19]}$ that challenged the widely-held misconception that AAEMs exhibit poor conductivities (the $\mathrm{OH}^{-}$form AAEM used in this study exhibits a conductivity at $50{ }^{\circ} \mathrm{C}$ of $45 \pm 1 \mathrm{mS} \mathrm{cm}^{-1}$ when immersed in water; cf. $104 \pm 8 \mathrm{mS} \mathrm{cm}^{-1}$ for the PEM Nafion-115), ${ }^{[19]}$ it is concluded that there are no fundamental obstacles to the long-term operation of SAFCs containing AAEMs. Despite the above, some challenges remain. Prior combined d.c. and a.c. impedance electrochemical studies ${ }^{[8]}$ indicate that a significant source of performance loss is limited transport of $\mathrm{H}_{2} \mathrm{O}$ molecules, a stoichiometric reactant, to the cathode catalyst sites leading to mass transport derived voltage losses. The most pressing requirement is for the specific development of electrodes and catalysts that will improve AAEM-based SAFCs and AMDAFCs performances. State-of-the-art catalysed Ti-mesh electrodes represent a technology that promises major advancement. ${ }^{[20]}$

Unlike that found with $\mathrm{KOH}(\mathrm{aq})$-electrolyte AFCs, the use of alcohol fuels is viable. AAEMs can exhibit reduced intrinsic methanol permeabilities $\left(5.4 \times 10^{-7} \mathrm{~cm}^{2} \mathrm{~s}^{-1}\right.$ for the AAEM compares with $19 \times 10^{-7} \mathrm{~cm}^{2} \mathrm{~s}^{-1}$ for Nafion-115), ${ }^{[12]}$ hence, thinner polymer electrolytes, with reduced absolute ionic resistances, can be used in AMDAFCs. The philosophy described above represents one of two fundamentally different approaches in relation to AMDAFCs: Demarconnay et al. argue that the addition of sodium hydroxide (up to $4 \mathrm{~mol} \mathrm{dm}^{-3}$ ) into the aqueous fuel supply is essential for adequate performances (currently $19 \mathrm{~mW}$ $\left.\mathrm{cm}^{-2}\right) \cdot{ }^{[20,21]}$ Indeed the maximum methanol/oxygen fuel cell performance obtained with this AAEM is $1.2 \mathrm{~mW} \mathrm{~cm}^{-2}$ at $50{ }^{\circ} \mathrm{C}$ (increases to $8 \mathrm{~mW} \mathrm{~cm}^{-2}$ with thinner AAEMs). ${ }^{[22]}$ However, our philosophy of $\mathrm{CO}_{2}$ tolerance, in the absence of aqueous electrolyte, is validated by the reduced carbonate content observed in the post-mortem of a deliberately carbonated AAEM that was tested over 6 hours in a methanol/air fuel cell (see supplementary information, the normalised carbonate peak intensity decreased from 0.3 to $0.06 \pm 0.05$ in all the methanol/air and methanol $/ \mathrm{O}_{2}$ tests conducted). The pros and cons of adding alkali to the alcohol supply is left open to continued scientific debate.

\section{Experimental Section}

Morgane ${ }^{\circledR}$ ADP100-2 (Solvay S.A., Belgium) was the AAEM used in this study; this cross-linked and partially fluorinated quaternaryammonium-type anion-exchange membrane was supplied in the $\mathrm{Cl}^{-}$anion form and has a maximum use temperature of $60^{\circ} \mathrm{C}$ and an ion-exchange capacity of $1.3 \mathrm{mmol}\left(\mathrm{Cl}^{-}\right) \mathrm{g}_{\mathrm{dry}}{ }^{-1}$. The properties in Table 1 were determined using previously reported procedures. ${ }^{[12,18,23]}$ The membrane samples were exchanged to the $\mathrm{CO}_{3}{ }^{2-}$ form immediately prior to any testing by immersion in a large excess of aqueous $\mathrm{K}_{2} \mathrm{CO}_{3}$ $\left(1 \mathrm{~mol} \mathrm{dm}^{-3}\right)$ at room temperature for $1 \mathrm{~h}$ with two changes of solution to ensure complete exchange. Subsequently, the AAEM samples were obtained after thorough washing in water to remove the excess $\mathrm{K}_{2} \mathrm{CO}_{3} . \mathrm{CO}_{3}{ }^{2-}$-free aqueous $\mathrm{KOH}\left(1 \mathrm{~mol} \mathrm{dm}^{-3}\right)$ was used as exchange solution to produce the $\mathrm{OH}^{-}$analogues (for benchmarking). The samples were characterised with Raman spectroscopy (Perkin Elmer System $2000 \mathrm{FT}$-Raman/near-IR spectrometer); this technique is very sensitive to the presence of $\mathrm{CO}_{3}{ }^{2-}$ and is rapid in that the ionomers can be studied without any preparative steps such as drying and dispersion in potassium bromide. All Raman spectra of the AAEM samples were normalised with respect to the characteristic $v_{12}$ band located at $1004 \mathrm{~cm}^{-1}$ attributable to benzyl groups on the polymer chains. ${ }^{[24]}$

Prefabricated electrodes were purchased from PEMEAS (Somerset, NJ, U.S.A) and contained a Pt/C (20\%mass, $\left.0.5 \mathrm{mg}_{\mathrm{Pt}} \mathrm{cm}^{-2}\right)$ catalyst. $^{\left[{ }^{[]^{\prime}}\right.}$ The electrodes $\left(25 \mathrm{~cm}^{2}\right)$ were coated with an alkaline interface polymer as previously reported. ${ }^{[6]}$ The AAEM and treated electrodes were assembled into the fuel cell fixture $(5 \times 5 \mathrm{~cm})$ at a torque of 5.5 $\mathrm{N} \mathrm{m}$ without pre-pressing into MEAs. This unusual procedure was intentional to allow the easy separation of the electrodes from the membrane electrolyte, which they did cleanly with no catalyst adhering to the membrane. This importantly allowed for the same electrodes to be used in all fuel cell tests and for the rapid postmortem examination of each post-test sample of AAEM. Fuel cell testing was conducted using the standard test protocols established 
in our laboratories ${ }^{[8,12]}$ (fuel cell temperature of $50^{\circ} \mathrm{C}$ with pre-heated $\mathrm{H}_{2}$ and air supplied at $2 \mathrm{dm}^{3} \mathrm{~min}^{-1}$ flow rates and $\mathrm{RH}=100 \%$ ). High reactant stoichiometries were deliberately chosen to minimize mass transport interferences. Beginning-of-life cell steady-state polarization curves were collected under galvanostatic control. All current and power densities are referred to the geometric area of the electrodes. Three fuel cell tests were conducted on different samples of the $\mathrm{CO}_{3}{ }^{2-}$-exchanged AAEM and three for different samples of the $\mathrm{OH}^{-}-$ exchanged membrane (the same electrodes, freshly ion-exchanged as appropriate, were used for all six tests: order $=\mathrm{CO}_{3}{ }^{2-} \rightarrow \mathrm{OH}^{-} \rightarrow$ $\mathrm{CO}_{3}^{2-} \rightarrow \mathrm{CO}_{3}^{2-} \rightarrow \mathrm{OH}^{-} \rightarrow \mathrm{OH}^{-}$). The internal resistances of the fuel cells were determined using in situ electrochemical impedance spectroscopy as described previously. ${ }^{[8]}$

Metanol/air tests were conducted with an anode electrode consisting of Toray paper coated with HISPEC 6000 PtRu black catalyst (Alpha Aesar, $4 \mathrm{mg} \mathrm{cm}^{-2}$ ) using an ink containing the alkaline ionomer binder and ethyl acetate. The cathode electrode was similar but contained HISPEC 1000 Pt black catalyst $\left(4 \mathrm{mg} \mathrm{cm}^{-2}\right)$. Aqueous methanol (2 mol dm ${ }^{-3}, 10 \mathrm{~cm}^{3} \mathrm{~min}^{-1}$, preheated to $50^{\circ} \mathrm{C}$ ) was supplied to the anode and the cathode supply was as above.

\section{Acknowledgements}

We thank the EPSRC for funding (contract GR/S60709/01); Henryk Herman (Actinic Technology and University of Surrey) for his assistance with the FT-Raman spectroscopy; Solvay S.A. (Brussels, Belgium) for providing the anion-exchange membrane.

\section{Keywords: Anion-Exchange Membrane Carbon Dioxide} Tolerance $\cdot$ Conducting Materials · Energy Conversion · Solid Alkaline Fuel Cell

[1] S. F. J. Flipsen, J. Power Sources 2006, 162, 927-934.

[2] H. A. Gasteiger, S. S. Kocha, B. Sompalli, F. T. Wagner, Appl. Catal. B Environ. 2005, 56, 9-35

[3] S. Gair, A. Cruden, J. McDonald, T. Hegarty, M. Chesshire, J. Power Sources 2006, 154, 472-478.
[4] G. F. McLean, T. Niet, S. Prince-Richard, N. Djilali, Int. J. Hydrogen Energy 2002, 27, 507-526.

[5] A. Tewari, V. Sambhy, M. Urquidi MacDonald, A. Sen, J. Power Sources 2006, 153, 1-10

[6] J. R. Varcoe, R. C. T. Slade, E. Lam How Yee, Chem. Commun. 2006, 1428-1429.

[7] E. Agel, J. Bouet, J. F. Fauvarque, J. Power Sources 2001, 101, 267-274.

[8] J. R. Varcoe, R. C. T. Slade, G. L. Wright, Y. Chen, J. Phys. Chem. B 2006, 110, 21041-21049.

[9] K. Matsuoka, Y. Iriyama, T. Abe, M. Matsuoka, Z. Ogumi, J. Power Sources 2005, 150, 27-31.

[10] C. Coutanceau, L. Demarconnay, C. Lamy, J.-M. Léger, J. Power Sources 2006, 156, 14-19.

[11] E. H. Yu, K. Scott, J Power Sources 2004, 137, 248-256.

[12] J. R. Varcoe, R. C. T. Slade, E. Lam How Yee, S. D. Poynton, D. J. Driscoll, D. C. Apperley, Chem. Mater. 2007, 19, 2686-2693.

[13] K. Matsuoka, Y. Iriyama, T. Abe, M. Matsuoka, Z. Ogumi, J. Electrochem Soc. 2005, 152, A729-A731.

[14] R. J. Lousenberg, J. Polym. Sci.: Part B; Polym. Phys. 2004, 43, 421-428.

[15] Y. Wang, L. Li, L. Hu, L. Zhuang, J. Lu, B. Xu, Electrochem. Commun. 2003, 5, 662-666.

[16] J. S. Spendelow, A. Wieckowski, Phys. Chem. Chem. Phys. 2007, 9, 2654-2675.

[17] M. Ciureanu, R. Roberge, J. Phys. Chem. B 2001, 105, 3531-3539.

[18] J. R. Varcoe, Phys. Chem. Chem. Phys. 2007, 9, 1479-1486.

[19] J. R. Varcoe, R. C. T. Slade, Solid State lonics 2005, 176, 585-597.

[20] E. H. Yu, K. Scott, J. Appl. Electrochem. 2005, 35, 91-96.

[21] L. Demarconnay, S. Brimaud, C. Coutanceau, J.-M. Léger, J. Electroanal. Chem. 2007, 601, 169-180.

[22] J. R. Varcoe, R. C. T. Slade, Electrochem. Commun. 2006, 8, 839-843.

[23] R. F. Silva, M. De Francesco, A. Pozio, J. Power Sources 2004, 134, 18-26.

[24] T. N. Danks, R. C. T. Slade, J. R. Varcoe, J. Mater. Chem. 2003, 13, 712-721.

Received: ((will be filled in by the editorial staff))

Published online: ((will be filled in by the editorial staff)) 
Entry for the Table of Contents (Please choose one layout)

Layout 2:

COMMUNICATION

This study presents a new class of fuel cell, the metal-cation-free solid alkaline fuel cell, as a solution to the carbonation problem of alkaline fuel cells. This is the first reported evaluation of a carbonate-form metal-cation-free alkaline membrane in a fuel cell. Contrary to prior wisdom, it is demonstrated that when operated in a fuel cells, the carbonate content of such membranes decreases; surprisingly, the power performance is also higher than when the equivalent hydroxide-form membranes

J. R. Varcoe, ${ }^{*}$ L. A. Adams, S. D.

Poynton, C. Tamain, R. C. T. Slade

Page No. - Page No.

A carbon dioxide tolerant aqueouselectrolyte-free anion-exchange membrane alkaline fuel cell 